At-Turats

Jurnal Pemikiran Pendidikan Islam

journal homepage: http://jurnaliainpontianak.or.id/index.php/atturats

\title{
MANTRA PESISIR (PERTEMUAN TRADISI DAN "ILMU" MASYARAKAT ISLAM PESISIR)
}

\author{
Hariansyah \\ Fakultas Tarbiyah dan Ilmu Keguruan (FTIK) \\ Institut Agama Islam Negeri (IAIN) Pontianak \\ Email: shah4shah19@gmail.com
}

\begin{abstract}
A B S T R A C T
Spells illustrating language power able to influence even to dominate souls. This article shows that human psychology (traditionally seashore community or cosmopolitan community) basically hard to self release from spells and supertition world? Is spell and supertition world forms of human psychology primordial characteristic? Psychology explanation about magic practice cause existence and spells more certainty because the effectiveness of charms that spells promised. It description towards bibliography study methods and narration analysis. Narrative analysis making flashback after construction theme, investigating social background and fighting ideas domination to draw dominant value, giving hidden intention from ideas (text) and reflecting continuity and review ideas on text, next reconstructing and narating to become complete story until become ideology.
\end{abstract}

Key words: spells, tradition, islamic and intellectual heritage

\section{PENDAHULUAN}

Mantra ${ }^{1}$ keberadaannya dianggap tradisi lisan tertua di dunia. Sebagai produk dari tradisi lisan, sebagaimana disinyalir oleh Chris Eipper ${ }^{2}$, mantra sangat mudah dipahami melalui pendekatan analisis naratif. Mantra ditafsirkan sebagai objek ekspresif dari [apa yang kemudian dikenal sebagai] "jimat" yang berakibat memunculkan efek kekhawatiran dan ketegangan

\footnotetext{
${ }^{1}$ Mantra diambil dari kata sansekerta yaitu "mantra" atau "manir" yang merujuk pada kata-kata dalam kitab suci umat Hindu, Veda. Dalam masyarakat Melayu, mantra atau juga dikenal sebagai jampi, serapah, atau seru adalah sejenis pengucapan yang terdengar seperti puisi yang mengandung unsur sihir dan ditujukan untuk mempengaruhi atau mengontrol sesuatu hal untuk memenuhi kenginan penuturnya. Antara lain, mantra merupakan ayat yang dibaca untuk melakukan sihir, yaitu melakukan sesuatu secara kebatinan, seperti menundukkan atau melemahkan musuh. Selain itu mantra dianggap memiliki kekuatan gaib yang luar-biasa
}

imajiner yang sangat menghantui. Dalam prakteknya, mantra terindikasi permainan metafora. Gagasan bahwa mantra merupakan tradisi lisan tertua didukung oleh riset yang dilakukan oleh Brian Moeran ${ }^{3}$ yang berani mengklaim bahwa magic dan mantra merupakan salah satu tema diskusi sekaligus teori tertua dalam antropologi. Magic tidak hanya berkohorensi secara spesifik menunjuk pada masyarakat

yang memungkinkan pembacanya mengontrol seseorang atau alam.

${ }^{2}$ Chris Eipper.The Magic in the Magic Pudding. The Australian Journal of Anthropology. Volume 10, Issue 2 August 1999, Pages 192-212. http://onlinelibrary. wiley.com/doi/10.1111/j.18359310.1999.tb00020.x/full.

${ }^{3}$ Brian Moeran Business, Anthropology, and Magical Systems: The Case of Advertising. Journal Ethnographic Praxis in Industry Conference. Volume 2014, Issue 1 October 2014, Pages 119-132. http://onlinelibrary. wiley.com/doi/10.1111/1559-8918.01016/ full. 
"primitif", tapi telah merambah ke masyarakat kontemporer. Bersandar pada gagasan ini menghantarkan riset Brian Moeran pada kesimpulan bahwa magic atau mantra bahkan dalam peradaban modern ini telah merasuki dunia periklanan. Sistem iklan yang melibatkan magi terlihat jelas dalam praktek bisnis sebagai manifestasi dari bentuk-bentuk tertentu yang memaksa untuk memasukkan sistem magis ke dalam praktek kapitalisme. Dalam perspektif yang lebih menantang, Mark S. Mosko ${ }^{4}$ mensinyalir bahwa kebanyakan laporan penelitian etnografis melaporkan bahwa sudah ada praktik magis dalam praktik agama dan budaya.

Bahkan seperti disinyalir oleh David

J. Collins bahwa dalam sejarah panjang Barat pun, sejak abad pertengahan juga sudah mengenal praktek magic, sihir, mantra dan sejenisnya berikut bagaimana mantra itu berkembang dan dipergunakan. ${ }^{5}$ Penelitian antropologi yang dilakukan Rachel Morgain 6 membuktikan penggunaan mantra magic justru diambil dari Alkitab. Tradisi ini juga terjadi pada penggunaan amulets di kalangan masyarakat di Palestina, mangkuk sihir di kalangan masyarakat Babilonia, bermacam teks magis dari Kairo Geniza hingga buku magis dari Babilonia dan beberapa lokasi lainnya. Sehubungan dengan konteks ini, sangat beralasan jika Patric V. Giesler ${ }^{7}$ mencuatkan definisi tradisional tentang

\footnotetext{
${ }^{4}$ Mark S. Mosko. Cards on Kiriwina: Magic, Cosmology, and the 'Divine Dividual' in Trobriand Gambling. Journal Oceania. Volume 84, Issue 3 November 2014 Pages 239-255. http://onlinelibrary.wiley.com/doi/ 10.1002/ocea.5058/full.

${ }^{5}$ David J. Collins. Magic in the Middle Ages: History and Historiography. Journal History Compass. Volume 9, Issue 5 May 2011 Pages 410-422. http://onlinelibrary.wiley. com/ doi/10.1111/j.14780542.2011.00776.x/full.

6 Rachel Morgain. Special Issue: Anthropological Theologies: Engagements and Encounters. The Alchemy of Life: Magic, Anthropology and Human Nature in a Pagan Theology. The Australian Journal of
}

mantra yang dimaknai sebagai 'keajaiban' sekaligus serangkaian dikotomi: agama versus sihir khususnya dengan menyoroti pentingnya konteks pada satu budaya tertentu. Sihir dan mantra hanya dapat dipahami sebagai bagian terpadu dari dua dunia yang sangat kontras ini.

Secara genealogi, di abad pertengahan, mantra telah berkembang sedemikian rupa di Eropa berikut isi dan peredaran teks magisnya. Bahkan hingga merambah ke area lain dari agama dan budaya abad pertengahan hingga awal abad modern. ${ }^{8}$ Begitu pun sebelum Islam masuk Nusantara, mantra dikenal dalam bentuk sastra lisan. Namun terjadi perubahan mendasar ketika Islam masuk ke Nusantara dengan membawa tradisi tulisan maka mantra pun lantas ditulis. Mantra jenis ini penggunaannya diikuti dengan gambargambar atau tulisan yang disebut jimat. Dalam perkembangan berikutnya mantra juga ditulis menggunakan aksara ArabMelayu. Pada saat itu, teks mantra terkadang memuat teks dengan unsur tasawuf, fikih, peramalan dan obatanobatan tradisional. Pada giliran berikutnya, mantra juga ditulis demi kepentingan ekonomis yang pada umumnya bercirikan tradisi agraris atau tradisi maritim.

Anthropology. Volume 24, Issue 3 December 2013 Pages 290-309. http://onlinelibrary.wiley.com/ doi/10.1111/taja.12052/full

${ }^{7}$ Patric V. Giesler. Magic, Witchcraft and the Otherworld: An Anthropology. Journal of the American Ethnological Society. Volume 29, Issue 1 February 2002. Pages 208209.

8 Catherine Rider. Magic and Impotence: Recent Developments in Medieval Historiography. Journal History Compass. Volume 5, Issue 3 May 2007 Pages 955-962.

http://onlinelibrary.wiley.com/doi/10.1111/j.14780542.2007.00431.x/full 
Kini, mantra telah dikenal luas di masyarakat. Pada awalnya, mantra mengacu pada bahan ramuan obat-obatan, seperti dedaunan, air, akar-akaran dan lainlain. Mantra juga mengacu pada sesuatu yang dibacakan oleh "dukun" atau "orang pintar." 9 Dilemanya, secara diametral tradisi kontemporer berakar pada pemahaman 'mekanistik' pengetahuan modern sekaligus penolakannya terhadap pemikiran magis. Keprihatinan ini beresonansi dengan kritik terhadap "pemikiran takhayul" dan magis. Fakta ini memperlihatkan hubungan yang masih terasa tidak nyaman dalam tradisi keilmuan hingga lantas menjadi sangat delimitasi sebagai 'ilmu kemanusiaan'. ${ }^{10}$

'Berguru' hingga saat ini dipastikan sebagai satu-satunya cara memelajari mantra. Ditengarai, kondisi ini lebih disebabkan karena mantra bernilai eksklusif dan hanya dipahami sekaligus diyakini di kalangan terbatas disertai beberapa pantangan tertentu untuk menjamin "keampuhan" mantra. ${ }^{11}$ Diduga, motif "hasrat ingin berkuasa" juga menjadi motivasi terkuatnya.

Teks mantra 12 umumnya menggunakan bahasa lokal sebagai

\footnotetext{
${ }^{9}$ Berdasar orang yang membaca mantra, mantra dibedakan menjadi dukun dan 'orang berisi'. Dukun atau orang pintar adalah orang yang membaca mantra untuk kepentingan membantu orang lain, mengobati orang dari sakit dan mengusir makhluk halus yang mengganggu. Akan tetapi ada juga kalanya dukun membaca mantra untuk membuat celaka orang lain. Lain halnya dengan orang berisi, yakni orang yang membaca mantra untuk kepentingan diri sendiri seperti untuk kekebalan atau membuat dirinya menarik perhatian lawan jenis.

${ }^{10}$ Ann Jeffers. Interpreting Magic and Divination in the Ancient Near East. Journal Religion Compass. Volume 1, Issue 6 November 2007, Pages 684-694 http://onlinelibrary. wiley.com/doi/ 10.1111/j.17498171.2007.00047.x/full

${ }^{11}$ Menurut responden Rusba, orang [pelaku mantra] dilarang berjalan melewati bawah jemuran karena akan menyebabkan lunturnya "ilmu" yang sudah dituntut.

${ }^{12}$ Mantra adalah bunyi, suku kata, kata, atau sekumpulan kata-kata yang dianggap mampu "menciptakan perubahan" (misalnya perubahan spiritual). Mantra berasal dari tradisi Weda di India, kemudian menjadi
}

identitas sekaligus intellectual heritage. Gagasan ini setidaknya mendapat pembenaran sebagai mana terbukti di Eropa, mantra membentuk tradisi sosial, politik, agama hingga intelektual pada awal Eropa modern setidaknya pada periode antara tahun 1450 dan tahun 1750. Pada titik ini, mantra menjadi tradisi yang diciptakan. ${ }^{13}$

Mantra selalu berciri ${ }^{14}$ dalam bentuk puisi. Isinya merefleksikan kepercayaan yang berkembang pada waktu tertentu dan dibuat dengan tujuan tertentu pula. ${ }^{15}$ Biasanya, mantra bersifat magis yang bertujuan untuk menciptakan simpati. Agar "jadi", berkhasiat dan "ampuh", mantra membutuhkan pengamal dengan keyakinan yang sangat kuat. Jika tidak, mantra akan "tawar". 16 Namun patut disayangkan, karakter mantra selalu saja anonim karena tidak jelas siapa "penciptanya". Ditambah lagi dengan teknis penyebaran yang sangat ketat karena hanya menggunakan tradisi lisan dan mendapatkannya harus dengan cara "berguru" secara langsung kepada "orang pandai".

Mantra dikenal masyarakat Indonesia sebagai rapalan untuk maksud tertentu (maksud baik ${ }^{17}$ maupun maksud kurang baik). Mantra dipastikan

bagian penting dalam tradisi Hindu dan praktik seharihari dalam agama Buddha, Sikhisme dan Jainisme dan agama ketimuran.

${ }^{13}$ Thomas A. Fudge. Traditions and Trajectories in the Historiography of European Witch Hunting. Journal History Compass. Volume 4, Issue 3 May 2006 Pages 488-527.

http://onlinelibrary.wiley.com/doi/10.1111/j.14780542.2006.00310.x/full

${ }^{14}$ Ciri lain dari mantra: pertama, mantra terdiri dari beberapa rangkaian kata berirama; kedua, isinya berhubungan dengan kekuasaan gaib; ketiga, mantra diamalkan dengan memiliki tujuan tertentu dan keempat, mantra diwarisi dari perguruan atau melalui cara gaib seperti melalui keturunan atau mimpi.

${ }^{15}$ Mantra berburu rusa Sirih lontar pinang lontar terletak diujung muara Hantu buta jembalang buta aku angkat jembalang rusa

${ }^{16}$ Wancacara dengan responden Rusba, warga Dabong tanggal 9 November 2016.

${ }^{17}$ Contoh mantra untuk mengobati orang dari pengaruh makhluk halus. (Sihir lontar pinang, lontar terletak di 
mengandung daya magis yang begitu kuat. Setiap daerah di Indonesia umumnya memiliki mantra. Redaksi biasanya mantra menggunakan bahasa daerah masingmasing. Namun tak jarang, juga menggunakan bahasa "asing" seperti bahasa $\operatorname{Arab}^{18}$ (pengaruh Islam) dan bahasa Sanskerta (pengaruh Hindu Budha). Namun adakalanya juga beredaksi bahasa Indonesia. Hal ini menandakan bahwa dalam perkembangannya terjadi peleburan antara mantra dengan unsur-unsur Islam dan tradisi setempat di mana mantra itu hidup.

Dari perspektif psikologis, melalui kata yang berirama, mantra memungkinkan seseorang memasuki kondisi rileks, membantu bagi perapal mantra untuk melakukan visualisasi untuk kemudian memasuki level unconscious (bawah sadar) untuk menciptakan sugesti diri.

\section{PEMAKNAAN TERHADAP MANTRA}

Mantra selalu berkarakter apostrof. Ketika mantra diucapkan baik oleh dukun/orang pintar atau individu tertentu kepada orang tertentu, ucapan mantra itu tidak mengharuskan mendapatkan jawaban verbal melainkan jawaban dalam bentuk kekuatan magis. ${ }^{19}$ Mantra yang diucapkan selalu tertuju pada orang tertentu yang menjadi obyek tujuan mantra. Mantra tidak akan efektif pada orang yang bukan menjadi tujuan dari mantra. Selain itu, mantra juga amat ditentukan oleh tingkat "kepercayaan"

ujung bumi, Setan buta jembalang buta, aku sapa tidak berbunyi)

${ }^{18}$ Berdasar kajian sejarah, teks mantra memakai frase yang bercirikan Islam di Indonesia dimulai sejak abad ke-18. Ciri itu terlihat pada pemakaian kata sapaan atau frase, seperti bism illah al-rahman al-rah\}im, Allah, malaikat, Nabi Muhammad, dan ayat-ayat al-Qur'an.

${ }^{19}$ Contoh mantra pengobat sakit perut : "Gelang-gelang si gali-gali, malukut kepala padi Air susu keruh asalmu jadi, aku sapa tidak berbunyi" terhadap "kekuatan magis" mantra. ${ }^{20} \mathrm{Di}$ atas semua itu, redaksi dalam mantra memiliki kekhasan tersendiri, karena mantra bagi pelakunya dianggap suci, memiliki kekuatan magis, tidak diperkenankan diucapkan secara sembarangan, dijaga kemurniannya, dan diturunkan secara hati-hati dalam mata rantai "tertutup".

Mantra digali dan dilestarikan sebagai hasil dari imajinasi bawah sadar. Setidaknya ada kepercayaan tentang "kekuatan" magis dari alam supranatural seperti hantu, jin, setan, dan benda-benda keramat dan sakti. Kesemuanya itu dianggap secara bipolar memiliki pengaruh jahat yang bisa mengganggu, tetapi ada pula yang sebaliknya, justru membawa keberuntungan. ${ }^{21}$ Di titik ini, mantra sarat dengan nilai ambiguitas.

Berikut ini, lihatlah bagaimana Jan Fidrmuc and J. D. Tena menjelaskan sejauh mana ambiguitas mantra. Menurut Jan Fidrmuc and J. D. Tena ${ }^{22}$ di banyak negara Eropa, termasuk Inggris, angka 13 dianggap sial dan sementara itu hari Jumat tanggal 13 dipandang sebagai hari keberuntungan. Riset ini menemukan bukti bahwa orang yang lahir pada tanggal 13 atau mereka yang lahir pada hari Jumat tanggal 13 secara signifikan cenderung untuk menjadi tenaga kerja level rendah, mendapat upah yang lebih rendah atau lebih mungkin untuk tetap tidak menikah dibandingkan dengan orang yang lahir pada hari-hari lainnya.

\footnotetext{
20 Jacqueline Van Gent. Current Trends in Historical Witchcraft Studies. Journal of Religious History. Volume 35, Issue 4 December 2011 Pages 601-613 http://onlinelibrary. wiley.com/doi/10.1111/j.14679809.2011.01144.x/full

${ }^{21}$ Laura Watson Benedict. A Study of Bagobo Ceremonial, Magic and Myth. Journal of The New York Academy of Sciences. Volume 25, December 1916 Pages 1-308.

22 Jan Fidrmuc and J. D. Tena. Friday the 13th: The Empirics of Bad Luck. Journal Kyklos. Volume 68, Issue 3 August 2015 Pages 317-334. http://onlinelibrary. wiley.com/doi/10.1111/ kykl.12085/full
} 
Takhayul atau keyakinan bahwa satu peristiwa dapat menyebabkan petaka adalah fenomena yang sangat umum dan telah ada selama ratusan bahkan ribuan tahun yang lalu. Hal yang sama juga sangat mudah ditemukan dalam pemhamaman masyarakat Islam di pesisir Dabong, Kecamatan Kubu. Contohnya ada begitu banyak orang yang percaya bahwa nasib buruk dapat disebabkan oleh berjalan di bawah tangga, melihat seekor kucing hitam melintasi jalan, larangan berjalan di bawah tali di antara tiang jemuran, membuka payung di dalam ruangan, menumpahkan garam atau melanggar cermin. Di sisi lain, menemukan tapal kuda atau empat lembar daun semanggi atau membawa jimat tertentu malah diyakini bisa membawa keberuntungan dan menangkal setan. Namun, percaya terhadap angka keberuntungan atau tidak memiliki keberuntungan tampaknya akan dinilai sebagai sesuatu yang tidak ada dasar rasionalnya.

Pemikiran magis dapat muncul bahkan kepada orang yang rasional sekalipun. Pemikiran magis lebih mungkin bisa dipercaya dengan bobot yang jauh lebih tinggi jika kemampuan yang dimiliki seseorang tak sebanding dengan kenyataan. Selain itu akan mudah berkembang jika terjadi peristiwa pemicu yang terkadang dikaitkan dengan hasil prediksi yang lebih baik.

Rasional atau tidak, pemikiran magis memiliki konsekuensi penting terutama berhubungan dengan keyakinan tentang keberuntungan atau sebaliknya. Di Inggris, 28 persen dari semua jalan tidak memiliki nomor 13. Beberapa orang menolak memulai usaha baru, melakukan pembelian dengan budget besar atau

\footnotetext{
${ }^{23}$ Jacqueline D. Woolley, Katrina E. Phelps, Debra L. Davis, and Dorothy J. Mandell. Where Theories of Mind Meet Magic: The Development of Children's Beliefs about Wishing. Journal Child Development. Volume 70, Issue 3 May/June 1999 Pages 571-587. http://onlinelibrary.wiley.com/doi/10.1111/14678624.00042/full
}

membuat keputusan penting, bahkan hingga menolak meninggalkan rumah pada hari Jumat yang jatuh di tanggal 13. Sebuah laporan terbaru menemukan bahwa penerbangan pada hari Jumat 13 Juni 2014 harga tiketnya jauh lebih murah daripada penerbangan pada hari-hari lain di bulan itu di Austria, Perancis, Inggris dan Swedia.

\section{MISTERI MANTRA}

Jika dicermati bahasa mantra
umumnya bernarasi esoterik, sukar dipahami, bahkan mungkin tidak punya arti secara nominal. Bagian terpenting dari mantra bukanlah pada dapat atau tidaknya dipahami tetapi lebih pada sisi kemanjurannya. ${ }^{23}$ Selanjutnya, dalam riset Woolley et.al ditemukan bahwa pengetahuan dan keyakinan akan kemanjuran mantra dalam formasi pengetahuan tentang hubungan jiwa-fisik memunculkan keyakinan dalam pikiran tentang berbagai teori mengenai mantra. Sehubungan dengan hal ini, menurut Rosengren and Hickling ${ }^{24}$ ketika mantra diucapkan pada saat itu mantra mewakili sejumlah mekanisme mental yang dipersepsikan sebagai "yang masuk akal", namun penjelasan magis tertentu sering kali melanggar harapan kausal mereka.

Karenanya, jika dipetakan mantra berkarakter: pertama, mantra sama sekali tidak berhubungan dengan pemahaman. Karenanya, mantra adalah ucapan yang tidak perlu dipahami, karena mantra dipersepsikan hanya sekedar "permainan" bahasa belaka. Kedua, mantra hanyalah mantra: hanya berisi satu tujuan. Tujuannya hanya secara efektif memengaruhi siapa

\footnotetext{
${ }^{24}$ Karl S. Rosengren, Anne K. Hickling. Seeing Is Believing: Children's Explanations of Commonplace, Magical, and Extraordinary Transformations. Journal Child Development. Volume 65, Issue 6 December 1994 Pages: 1605-1626. http://onlinelibrary.wiley.com/ doi/ 10.1111/j.1467-8624.1994.tb00838.x/full
} 
saja yang menjadi sasaran mantra itu. Mantra berkemampuan mengubah pikiran magical suggestive yang menghasilkan efek yang begitu kuat. Mantra dipercayai dapat memengaruhi masa depan dalam konteks mampu mengubah sesuatu menjadi buruk atau menjadi lebih baik. ${ }^{25}$ Meski mantra pada individu adolesen tak berkorelasi sama sekali dengan kepuasan hidup bahkan justru menstimulasi bereskalasinya peluang mengalami mimpi buruk pada saat tidur hingga tak jarang menyebabkan individu adolesen menyembunyikan pengaruh mantra bagi kepuasan kehidupan mereka. ${ }^{26}$

Dengan demikian, mantra membuat chemistry sedemikian rupa antara manusia dengan dunia penuh misteri dengan beragam tujuan. Meski keduanya memiliki "dunianya" sendiri. Dunia mantra menawarkan pengalaman estetis intelektual yang unik dan khas. Bahkan di tingkat tertentu sarat pengalaman "ajaib" yang membuka jalan baru untuk menginvestigasi isu-isu estetika kontemporer. ${ }^{27}$ Bahkan dunia mantra memuat ruang fisik bagi tindakan manusia. Ini mengasumsikan ruang fisik itu berarti penting memengaruhi perilaku yang terjadi melalui ruang kosong. ${ }^{28}$ Bahkan lebih jauh dari itu, mantra memberi cara lain melihat hubungan antara ruang fisik dan perilaku manusia dalam konteks isu-isu kontemporer dalam ilmu sosial.

\footnotetext{
${ }^{25}$ Eugene Subbotsky. Children's and Adults' Reactions to Magical and Ordinary Suggestion: Are Suggestibility and Magical Thinking Psychologically Close Relatives? British Journal of Psychology. Volume 98, Issue 4 November 2007 Pages 547-574 http://onlinelibrary.wiley.com/doi/10.1348/000712606 X166069/full

${ }^{26}$ Eugene Subbotsky. Can Magical Intervention Affect Subjective Experiences? Adults' Reactions to Magical Suggestion. British Journal of Psychology. Volume 98 Issue $\quad 4 \quad$ November 2007. http://onlinelibrary.wiley.com/doi/10.1348/000712608 X368270/full

${ }^{27}$ Jason Leddington. The Experience of Magic. The Journal of Aesthetics and Art Criticism. Volume 74 Issue 3 Summer 2016. Pages 253-264
}

\section{MEMBACA DAN MEMAKNAI MANTRA}

Pendeskripsian artikel ini mengenai mantra berikut makna, misteri dan relasinya dengan agama dan tradisi ini mengacu pada metode studi kepustakaan dan analisis narasi. Studi kepustakaan ditujukan untuk menganalisa berbagai gagasan dalam berbagai naskah literatur mengenai tema tentang mantra sebagai titik fokus analisis. Sementara itu, analisis naratif membantu untuk menganalogikan (teks) sebagai sebuah alur cerita dengan langkah metodologis: pertama, membuat kilas balik setelah tema dikonstruksi. Kedua, menelusuri latar sosial berikut pertarungan dominasi antar-gagasan untuk memetakan nilai dominan. Ketiga, memerikan makna tersembunyi dari gagasan (teks). Keempat, merefleksikan kontinuitas dan kajian ulang gagasan yang termuat dalam teks. ${ }^{29}$ Detail pemerian dan cara mengkonstruksi gagasan untuk bisa dimengerti menjadi sangat menentukan. Begitu banyak karya terdegradasi karena tidak lolos pada tahap proses seleksi, penekanan dan presentasi. ${ }^{30}$

Secara metodologis, narasi besar sebuah gagasan kemudian direkonstruksi dan dinarasikan hingga menjadi bagian cerita utuh hingga menjadi berideologi. ${ }^{31}$ Ideologi yang dimaksudkan dalam tulisan ini sebagai rangkaian proses memproduksi makna dan gagasan mengenai tema tentang mantra yang terkadang juga diintervensi oleh sistem keyakinan yang berada dalam

http://onlinelibrary.wiley. com/doi/10.1111/jaac.12290/full

${ }^{28}$ Robert David Sack. Magic And Space. Journal Annals of the Association of American Geographers. Volume 66, Issue 2 June 1976 Pages 309-321 http://onlinelibrary. wiley.com/doi/10.1111/j.14678306.1976.tb01092.x/full

29 Eriyanto, Analisis Naratif: Dasar-dasar dan Penerapannya dalam Analisis Teks Berita Media (Jakarta: Kencana, 2013), 10-11.

${ }^{30}$ Todd Gitlin, The Whole World is Watching: Mass Media in the Making and Unmaking of the New Left (California: University of California Press, 1990), 6.

${ }^{31}$ Eriyanto, Analisis Naratif, 8. 
area perdebatan antara diterima atau ditolak..$^{32}$

\section{RELASI ANTARA MANTRA, AGAMA, "ILMU" DAN TRADISI}

Ketika riset tentang tema ini dilakukan hingga artikel ini dilansir, penulis menemukan fakta bahwa mantra diyakini membawa berkah. Hingga kini, keyakinan itu terus bertahan. Karenanya, mantra sewajarnya lahir dari tradisi sebagai ekspresi kepercayaan. Mantra terintegrasi dalam kehidupan keseharian. Mantra tercipta dan tumbuh di masyarakat. Nyaris tak dapat dibantah jika mantra berhubungan erat dengan adat dan tradisi. Ada kesamaan antara magic (mantra) dengan interaksi sosial dalam kehidupan sehari-hari. Ada dialektika antara penalaran tentang mantra dengan penalaran keseharian. ${ }^{33}$

Karenanya, merujuk J.G. Frazer bahwa manusia selalu dihadapkan dengan usaha memecahkan berbagai persoalan hidup melalui akal dan sistem ilmu pengetahuan. Namun dalam kenyataannya akal dan sistem pengetahuan itu sangat terbatas, maka persoalan hidup yang tak terpecahkan itu kemudian dipecahkan melalui magic. Magic diartikan sebagai segala tindakan manusia untuk mencapai maksud tertentu melalui perantaraan kekuatan alam untuk memecahkan segala persoalan hidup yang dimensinya berada di luar batas kemampuan dan pengetahuan akalnya.

Fenomena mantra yang terkadang disertai dengan jimat dalam masyarakat Islam di Dabong sudah dikenal sejak lama. Jimat pada umumnya menggunakan teks

\footnotetext{
${ }^{32}$ John Fiske. Introduction to Communication Studies. (London: Sage Publication, 1990), 116. Lihat juga Eriyanto, Analisis Naratif, 221.

${ }^{33}$ Peter M. Nardi. Toward a Social Psychology of Entertainment Magic (Conjuring). Journal Symbolic
}

dari ayat al-Qur`an. Menjadi sangat menarik jika penggunaan jimat ini kemudian menjadi tradisi sekaligus mejadi representasi dari berkembangnya "ilmu" berikut bagaimana masyarakat di sana memaknainya. Dari riset yang dilakukan menunjukkan bahwa jimat yang digunakan oleh masyarakat Dabong bermacammacam, mulai dari jimat yang ditujukan untuk mengusir/melindungi gangguan makhluk halus atau Jin, jimat pagar rumah, jimat kekebalan, jimat untuk memudahkan usaha yang berlatar ekonomis, jimat penglaris, hingga jimat penyubur tanaman. Praktik ini dikombinasikan antara penggunaan jimat dengan unsur budaya lokal seperti beberapa ritual tertentu. Penggunaan jimat atau mantra bagi masyarakat Islam pesisir Dabong diyakini memiliki kekuatan luar biasa dan hanya dapat dilakukan oleh orang tertentu yang memiliki kekuatan supernatural, yang disebut sebagai dukun.

Pembuat jimat atau mantra (dukun) adalah orang yang dianggap memiliki kekuatan "ilmu" gaib yang melebihi "orang biasa". Dukun dianggap mengerti berbagai hal gaib yang tidak dimengerti masyarakat awam dan dipercayai memiliki kemampuan khusus untuk berkomunikasi dengan makhluk gaib. Karena ketidaktahuan masyarakat mengenai dunia gaib ini lantas masyarakat mengekspresikannya dengan tingkat kepasrahan yang tinggi kepada para dukun. Hubungan yang diwarnai kepasrahan itu akan semakin kuat apabila keajaiban dan semua yang di luar akal dapat dibuktikan dan dipenuhi oleh para dukun yang dipercaya secara fatalis oleh

Interaction. Volume 7, Issue 1 Spring 1984 Pages 25-42 http://onlinelibrary.wiley.com/doi/10.1525/si.1984.7.1. 25/ full 
masyarakat tersebut. Para dukun itu seolah tahu persis bahwa para pengguna jimat atau mantra itu adalah sekelompok masyarakat yang [sedang] menghadapi beragam persoalan yang secara rasional sulit diatasi.

Praktek pembuatan dan penggunaan jimat dengan atau tanpa menggunakan ayat al-Qur`an dan sejumlah bacaan lain yang diyakini berasal dari ajaran Islam tersebut ditengarai sudah berlangsung secara turunturun. Di antaranya menjadikan potonganpotongan ayat, satu ayat, ataupun beberapa ayat tertentu dikutip dan dijadikan sebagai sarana untuk menjadikan ayat al-Qur'an itu sebagai ilmu yang dibuat dengan beragam tujuan tertentu. Potongan ayat tertentu dari al-Qur'an dijadikan sebagai "jimat" atau "ilmu" yang dibawa kemana saja oleh orang yang meyakini jimat dan ilmu tersebut sebagai perisai diri, tolak balak atau menangkis serangan musuh dan unsur jahat lainnya. Di titik ini, ayat al-Qur'an telah bertransformasi menjadi "ilmu" yang diyakini memiliki kekuatan gaib. Melalui mantra atau jimat sejumlah orang yang meyakini kekuatan ilmu gaib yang terdapat "di dalam" mantra dan jimat merasa yakin akan kekuatan gaib yang mem-backing-i untuk dapat memberikan bantuan hingga memuluskan atau meraih semua keinginannya.

Berbagai fakta ini jika dibaca menggunakan perspektif psikoanalitik dapat dijelaskan bahwa mantra seolah menjadi kecirian bagi masyarakat primitif. Untuk memperjelas perdebatan ini, menarik mencermati gagasan yang dikemukakan Robert A. Segal 34 bahwa untuk mendeskripsikan tentang pengetahuan masyarakat 'primitif', C. G. Jung

\footnotetext{
${ }^{34}$ Robert A. Segal. Jung and Lévy-Bruhl. The Journal of Analytical Psychology. Volume 52, Issue 5 November 2007 Pages
}

menggunakan berbagai batasan teoritik dari Lucien Levy Bruhl (1857-1939) yang menegaskan bahwa konsepsi tentang masyarakat 'primitif' telah banyak disalahpahami oleh orang Barat modern. Term 'primitif' selalu mengarah pada dimensi mentalitas saja. Sementara berpikir 'primitif' dimaknai sebagai pemikirian 'mistis' atau 'pra-logis'. 'Mistis' berarti masyarakat "primitif" memaknai dunia sebagai identik dengan diri mereka sendiri. Hubungan mereka dengan dunia terbentuk dalam "partisipasi mistik". Sementara itu, pemikiran "primitif" sebagai suatu bentuk pemikiran acuh tak acuh terhadap kontradiksi. Term "primitif" merujuk pada semua hal yang identik dengan satu sama lain namun masih menunjukkan "adanya" perbedaan. Ada beberapa aspek yang membedakan antara konsepsi Jung dengan konsepsi Bruhl mengenai mentalitas 'primitif' melalui tiga cara utama. Pertama, berpikir "primitif" merupakan gejala psikologis yang inheren. Sedangkan menurut Bruhl berpikir 'primitif' harus dijelaskan secara sosiologis: berpikir 'primitif' terjadi karena mereka tinggal dalam keadaan tidak sadarkan diri. Kedua, bagi Jung, gagasan tentang "primitif" diuniversalisasi mentalitas. Bagi Bruhl, gagasan tentang "primitif" justru semakin digantikan oleh pemikiran modern. Bagi Jung, berpikir “primitif” merupakan kondisi psikologis awal dari semua manusia. Ketiga, Jung menghargai pemikiran "primitif" sedangkan Bruhl menganggap pemikiran 'primitif' sebagai sesuatu yang palsu. Berbeda dari Bruhl, Jung mengakuinya sebagai ekspresi dari cara kerja alam sadar manusia. 
Melanjutkan diskursus yang telah digulirkannya di atas, Robert A. Segal ${ }^{35}$ menyatakan bahwa secara umum diasumsikan bahwa pandangan Jung tentang mitos mantra dipahami secara vis-àvis dengan Freud. Segal berpendapat bahwa gagasan Jung mengenai mitos mantra jauh lebih luas. Tak dapat disangkal, teori Jung berbeda jauh dengan teori Freud yang menganggap bahwa subyek mitos mantra menjadi dunia eksternal dari pikiran manusia dan fungsi mitos mantra menjadi deskripsi dari dunia eksternal daripada ekspresi dari pikiran manusia. Para ahli yang menantang teori Jung menyatakan bahwa mitos mantra adalah rekan "primitif" ilmu pengetahuan yang seluruhnya modern. Bagi mereka, mitos mantra dan ilmu pengetahuan tidak kompatibel: ilmu selalu benar dan mitos mangtra selalu palsu; karena itu mitos mantra harus menjauh dari ilmu. Penolakan Jung bahwa dunia sebagai fungsi dari mitos mantra melambangkan respon bahwa mitos mantra dan ilmu pengetahuan tidak semestinya dijadikan sebagai saingan, sehingga mitos mantra yang tidak perlu pergi ketika ilmu datang.

Lebih jauh, berkembang pula kepercayaan akan kekuatan mantra yang berasal dan dikendalikan kekuatan supranatural masih bertahan hingga kini. Mantra, magic dan ramalan hanya dapat dipahami sebagai bagian terpadu dari kerangka berpikir semacam ini. Kerangka pikir yang dibangun berdasar kepercayaan

${ }^{35}$ Robert A. Segal. Jung's Very Twentieth-century View of Myth. The Journal of Analytical Psychology. Volume 48, Issue 5 November 2003 Pages 593-617. http://onlinelibrary.wiley.com/doi/10.1111/14655922.00422/full.

${ }^{36}$ Ann Jeffers. Interpreting Magic and Divination in the Ancient Near East. Journal Religion Compass. Volume 1, Issue 6 November 2007 Pages 684-694 http://onlinelibrary.wiley.com/doi/10.1111/j.17498171.2007.00047.x/full akan "berbagai keajaiban" dunia tak kasat mata hingga masuk ke dalam sistem intermediasi agama yang sudah bisa dipastikan akan begitu kompleks. ${ }^{36}$

Sebagai ilustrasi dapat dilihat bagaimana Graham M. Jones ${ }^{37}$ menemukan bahwa dalam tradisi Kristen Evangelis menyampaikan pesan agama terkadang menggunakan kekuatan magic dan trik untuk mengeksplorasi berbagai efek mantra untuk menghasilkan ekspresi kompleks untuk menggugah iman. Sehubungan dengan konteks ini, Chadwick 38 berhipotesa bahwa ada hubungan antara praktek ritual dan upaya memperkuat pemikiran dualistik modern. Sebaliknya, ada kontinum praktik dari ritual melalui skala kecil dan tindakan informal yang dilakukan secara rutin.

Dalam skala yang lebih mikro, beberapa responden di pesisir Dabong menyebutkan bahwa mantra terkadang [masih] digunakan hingga ke bagian terkecil dari tradisi masyarakat pesisir. Tradisi sebagai nelayan dan masyarakat maritim yang telah melekat kuat dalam batin psikologis masyarakat Dabong. Bagi mereka, "melaut" terkadang mengharuskan untuk menggunakan dalam situasi tertentu. Misalnya ketika terjadi badai angin, terkadang "memaksa" untuk menggunakan mantra 'memanggil' hantu laot untuk "membantu" selamat dari terpaan badai angin laut yang bisa saja berpotensi mengaramkan kapal di tengah laut. Bahkan responden Rusba menegaskan mantra juga [terkadang masih] digunakan dalam

\footnotetext{
${ }^{37}$ Graham M. Jones. Magic with a Message: The Poetics of Christian Conjuring. Journal Cultural Anthropology. Volume 27, Issue 2 May 2012 Pages 193-214 http://onlinelibrary.wiley.com/doi/10.1111/j.15481360.2012.01140.x/full

${ }^{38}$ Adrian M. Chadwick. Routine Magic, Mundane Ritual: Towards a Unified Notion of Depositional Practice. Oxford Journal of Archaelogy. Volume 1, Issue 3 August 2012, Pages 283-315. http://onlinelibrary.wiley.com/doi/10.1111/j.14680092.2012.00390.x/ full.
} 
permainan sepak bola antarkampung dalam kesempatan perayaan acara tertentu. ${ }^{39}$

Akhirnya, tanpa berpretensi menyudahi dan menutup rapat ruang perdebatan tentang mantra ini, penulis mengetengahkan kritik tajam yang dikemukakan oleh Segal untuk dijadikan sebagai bahan renungan. Dengan narasi retorik, Robert A. Segal ${ }^{40}$ mengajukan beberapa pertanyaan atau malah kritik: apakah mungkin bagi seorang psikolog, menggunakan temuan ilmiah sosial untuk membuat klaim filosofis? Secara khusus, apakah mungkin juga bagi seorang ilmuwan sosial untuk menggunakan temuan ilmiah sosial untuk menentukan keberadaan Tuhan? Apakah Jung mengaku hanya seorang psikolog atau juga filsuf? Jika dia mengaku menjadi keduanya, dia meminta temuan psikologis untuk membuat klaim filosofis? Secara khusus, dia meminta temuan psikologis untuk menentukan keberadaan Tuhan?

\footnotetext{
${ }^{39}$ Riset Zsuzsanna Dömötör et. al. berhasil mengungkap bahwa ada relasi tradisi takhayul dalam olahraga. Perilaku takhayul bervariasi dengan jenis olahraga. Prevalensi indeks takhayul terus meningkatkan dengan meningkatnya tantangan, pentingnya kompetisi, serta dengan tingkat ketidakpastian menjadi juara. Selain itu, faktor budaya, tingkat pendidikan serta jenis kelamin berpengaruh kuat pada perilaku takhayul dalam olahraga. Selain itu, faktor kepribadian muncul untuk menengahi manifestasi dari perilaku. Atlet elit cenderung lebih superstisi dibanding atlet non-elit menjadi prediktor kuat lain dari takhayul dalam olahraga. Serangkaian faktor personal dan situasional kompleks berinteraksi dalam manifestasi perilaku takhayul dalam olahraga yang digunakan untuk pengaturan emosi dalam sebuah pencarian untuk kinerja yang lebih optimal. Lebih jelas lihat Zsuzsanna Dömötör, Roberto Ruíz-Barquín, and Attila Szabo. Superstitious Behavior in Sport: A literature Review. Personality and Social Psychology. Scandinavian Journal of Psychology. Volume 57, Issue 4 August 2016 Pages 368-382. http://onlinelibrary.wiley.com/doi/10.1111/sjop.12301/f ull. Lihat pula Riset Michaéla C. Schippers dkk. juga membahas aspek psikologis ritual takhayul dalam
}

\section{PENUTUP}

Mantra magic seperti dilansir Joseph Angel ${ }^{41}$ kerap dianggap sebagai pendekatan yang sistematis tetapi tidak biasa untuk pentingnya ruang fisik untuk tindakan manusia. Ini mengasumsikan ruang fisik itu sendiri memiliki arti penting dalam memengaruhi perilaku dan tindakan yang seakan terjadi melalui "ruang kosong". Pada akhirnya gagasan ini kemudian memengaruhi perkembangan intelektual dan menambahkan dimensi lain untuk melihat hubungan antara ruang fisik dan perilaku manusia dalam konteks kontemporer.

Bahkan dalam batas terjauhnya, mantra yang tadinya dianggap sebagai sisasisa dari budaya dan tradisi masyarakat tradisional, tiba-tiba saja merasuk dan sekaligus menjadi ciri masyarakat dapat cakupan yang lebih luas. Termasuk masyarakat modern saat ini yang disebutnya sebagai "masyarakat pagan

olahraga terutama pada kasus olahragawan kelas atas yang secara khusus berkomitmen untuk membuat ritual sebelum pertandingan berlangsung (komitmen ritual). Riset ini membuktikan komitmen ritual lebih besar ketika: (a) ketidakpastian akan memenangi pertandingan lebih tinggi; dan (b) pentingnya pertandingan yang akan dijalani. Ketegangan psikologis berpengaruh penting pada ketidakpastian komitmen ritual selain locus of control eksternal. Lihat Michaéla C. Schippers, Paul A. M. Van Lange. The Psychological Benefits of Superstitious Rituals in Top Sport: A Study Among Top Sportspersons. Journal of Applied Social Psychology. Volume 36, Issue 10 October 2006, Pages 2532-2553. http://onlinelibrary. wiley.com/doi/10.1111/j.00219029.2006.00116.x/full.

${ }^{40}$ Robert A. Segal. Jung as Psychologist of Religion and Jung as Philosopher of Religion. The Journal of Analytical Psychology. Volume 55, Issue 3 June 2010 Pages 361-384. http://onlinelibrary.wiley.com/doi/10.1111/ j.14685922.2010.01848.x/full

${ }^{41}$ Joseph Angel. The Use of the Hebrew Bible in Early Jewish Magic. Journal Religion Compass. Volume 3, Issue 5 September 2009 Pages 785-798 http://onlinelibrary .wiley.com/doi/10.1111/j.17498171.2009.00167.x/full 
kontemporer". Lihat bagaimana fakta ini seolah menjadi kesimpulan dari gagasan yang dikemukakan Rachel Morgain 42 berikut ini: "Tradisi pagan kontemporer berakar pada pemahaman tentang sesuatu yang dinilai sakral sekaligus 'mekanisasi' ilmu pengetahuan modern dan penolakannya terhadap pemikiran magis. Penolakan itu didasari bahwa pemikiran magis berdampak pada pelibatan dalam hal penindasan, kerusakan lingkungan dan kolonialisme berpikir. Gagasan ini memperlihatkan hubungan yang [masih] tidak nyaman antara pengetahuan 'nonrasional' sebagai salah satu bentuk pengetahuan di satu pihak dan tindakan men-derasionalisasi di lain pihak yang kini dianggap sangat mendelimitasi nilai kemanusiaan."

Implikasi dari gagasan ini menghantarkan pada adu argumen tentang seperti apa posisi mantra sebenarnya dalam spektrum keilmuan. Di tengah diskursus sengit mengenai hal ini, temuan riset Rountree dan Monagan ${ }^{43}$ seolah memberi gagasan alternatif bagi semua pihak yang menginginkan menemukan cara bagaimana seharusnya "memperlakukan" mantra ini. Bagi Rountree ${ }^{44}$, perdebatan antara teori

42 Rachel Morgain. Special Issue: Anthropological Theologies: Engagements and Encounters. The Alchemy of Life: Magic, Anthropology and Human Nature in a Pagan Theology. The Australian Journal of Anthropology. Volume 24, Issue 3 December 2013, Pages 290-309. http://onlinelibrary.wiley.com/doi/10.1111/taja.12052/f ull.

43 Alfrieta Parks Monagan. The Anthropology of Magic. by Susan Greenwood. New York: Berg, 2009. p. 159. Journal Anthropology and Humanism. Volume 38, Issue 1 June 2013, Pages 102-103.

${ }^{44}$ Kathryn Rountree. How Magic Works: New Zealand Feminist Witches' Theories of Ritual Action. Journal Anthropology of Consciousness. Volume 13, Issue 1 March 2002 Pages 42-59. http://onlinelibrary.wiley.com/doi/ 10.1525/ac.2002.13.1.42/full. ilmiah tentang mantra dan ritual "ilmu hitam" telah menciptakan dikotomi: ilmu terhadap magic yang simbolis versus intelektualis sebagai tindakan melawan keyakinan sekaligus pemikiran. Uniknya, para praktisi magic atau mantra tidak "mengakui" eksisnya dikotomi itu. Namun, yang terlihat jelas mantra justru menggabungkan dimensi ekspresif, dramatikal, estetika dan nilai-nilai. Karenanya, magic dan mantra tidak antiilmu pengetahuan atau pseudo-sains tapi justru mengeksplorasi peran simbol dan energi yang teramat kuat eksis dalam mantra sebagai cara implementatif untuk beragam motif "pemberdayaan" dan praktik penyembuhan.

Hasil riset Fluke et.al. ${ }^{45}$ juga mempertegas statement di atas bahwa di tengah perubahan arus modernisasi yang kini telah merambah hingga daerah terpencil sekalipun membuktikan bahwa mantra yang terdiri dari tiga komponen: keyakinan nasib buruk, kepercayaan keberuntungan, dan keyakinan bahwa keberuntungan dapat diubah, ternyata ketiga hal itu masih memengaruhi sikap dan perilaku terhadap takhayul. ${ }^{46}$

\footnotetext{
${ }^{45}$ Scott M. Fluke, Russell J. Webster, Donald A. Saucier. Methodological and Theoretical Improvements in the Study of Superstitious Beliefs and Behaviour. British Journal of Psychology. Volume 105, Issue 1 February 2014 Pages 102-126. http://onlinelibrary.wiley.com/doi/10.1111/bjop.12008/ full

${ }^{46}$ Untuk menguatkan argument ini, lihat hasil riset Swee Hoon Ang, et.al. yang mengkaji dampak dari beberapa karakteristik takhayul (ambivalensi, aksesibilitas, dan relevansi) pada pilihan dan latency. Riset ini menyimpulkan bahwa sikap takhayul mempercepat penentuan pilihan. Produk yang menguntungkan secara ekonomis lebih mungkin dipilih jika dikaitkan dengan takhayul yang lebih mudah diakses. Temuan juga menunjukkan bahwa ketika takhayul relevan, efek dari takhayul negatif diperkuat daripada ketika takhayul tidak relevan. Untuk lebih jelas lihat Swee Hoon Ang,
} 
Penjelasan antropologi mengenai penyebab eksisnya praktik magic dan mantra disebabkan karena keyakinan mengenai efek manjur yang ditimbulkan oleh mantra. ${ }^{47}$ Pertanyaan serius yang layak dikemukakan mengenai hal ini: apakah secara psikologis manusia [tanpa mempertimbangkan posisi dan domisilinya: masyarakat pesisir yang masih tradisional atau masyarakat kosmopolitan sekalipun] pada dasarnya sulit melepaskan diri dari mantra dan dunia superstisi? Apakah mantra dan dunia superstisi merupakan karakteristik primordial pasikologis manusia?

\section{DAFTAR KEPUSTAKAAN}

Ang, Swee Hoon., Wai Kit Lai, Siew Meng Leong. The Effects of Superstition on Choice and Latency. Journal Psychology \& Marketing. Volume 31, Issue 12 November 2014. Pages 1074-1083. http://onlinelibrary.wiley.com/ doi/10.1002/mar.20754/full.

Angel, Joseph. The Use of the Hebrew Bible in Early Jewish Magic. Journal Religion Compass. Volume 3, Issue 5 September

Wai Kit Lai, Siew Meng Leong. The Effects of Superstition on Choice and Latency. Journal Psychology \& Marketing. Volume 31, Issue 12 November 2014. Pages 1074-1083. http://onlinelibrary.wiley.com/ doi/10.1002/mar.20754/full.
2009 Pages

$785-798$

http://onlinelibrary.wiley.com/doi/ 10.1111/j.1749-8171.2009.00167. $\mathrm{x} / \mathrm{full}$

Benedict, Laura Watson. A Study of Bagobo Ceremonial, Magic and Myth. Journal of The New York Academy of Sciences. Volume 25, December 1916 Pages 1-308.

Chadwick, Adrian M.. Routine Magic, Mundane Ritual: Towards a Unified Notion of Depositional Practice. Oxford Journal of Archaelogy. Volume 1, Issue 3 August 2012, Pages 283-315. http://onlinelibrary.wiley.com/doi/ $10.1111 /$ j.14680092.2012.00390.x/ full.

Collins, David J.. Magic in the Middle Ages: History and Historiography. Journal History Compass. Volume 9, Issue 5 May 2011 Pages 410422. http://onlinelibrary.wiley. com/ doi/10.1111/j.14780542.2011.00776.x/full.

Dömötör, Zsuzsanna, Roberto RuízBarquín, and Attila Szabo. Superstitious Behavior in Sport: A literature Review. Personality and Social Psychology. Scandinavian Journal of Psychology. Volume

\footnotetext{
${ }^{47}$ Craig T. Palmer, Lyle B. Steadman, Chris Cassidy, Kathryn Coe. The Importance of Magic to Social Relationships. Zygon Journal of Religion \& Science. Volume 45, Issue 2 June 2010, Pages 317-337. http://onlinelibrary.wiley.com/doi/10.1111/j.14679744. 2010. 01083.x/full. Lihat pula Karl Halvor Teigen, Pia C. Evensen, Dimitrij K. Samoilow, and Karin B. Vatne. Good Luck and Bad Luck: How to Tell the Difference. European Journal OF Social Psychology. Volume 29, Issue 8 December 1999 Pages 981-1010. http://onlinelibrary. wiley.com/doi/10.1002/(SICI)10990992(199912)29:8\%3C981::AIDJSP966\%3E3.0.CO;2-Z/full
} 
57, Issue 4 August 2016 Pages 368-382.

http://onlinelibrary.wiley.com/doi/ 10.1111/sjop.12301/full.

Eipper, Chris.The Magic in the Magic Pudding. The Australian Journal of Anthropology. Volume 10, Issue 2 August 1999, Pages 192-212. http://onlinelibrary.wiley. com/doi/10.1111/j.18359310.1999.tb00020.x/full.

Eriyanto, Analisis Naratif: Dasar-dasar dan Penerapannya dalam Analisis Teks Berita Media (Jakarta: Kencana, 2013), 10-11.

Fidrmuc, Jan and J. D. Tena. Friday the 13th: The Empirics of Bad Luck. Journal Kyklos. Volume 68, Issue 3 August 2015 Pages 317-334. http://onlinelibrary. wiley.com/doi/10.1111/kykl.1208 5/full

Fiske, John. Introduction to Communication Studies. (London: Sage Publication, 1990), 116.

Fluke, Scott M., Russell J. Webster, Donald A. Saucier. Methodological and Theoretical Improvements in the Study of Superstitious Beliefs and Behaviour. British Journal of Psychology. Volume 105, Issue 1 February 2014 Pages 102-126. http://onlinelibrary.wiley.com/doi/ 10.1111/bjop.12008/ full

Fudge, Thomas A.. Traditions and Trajectories in the Historiography of European Witch Hunting. Journal History Compass. Volume 4, Issue 3 May 2006 Pages 488527.

http://onlinelibrary.wiley.com/doi/ 10.1111/j.1478-

0542.2006.00310.x/full
Giesler, Patric V.. Magic, Witchcraft and the Otherworld: An Anthropology. Journal of the American Ethnological Society. Volume 29, Issue 1 February 2002. Pages 208209.

Gitlin, Todd, The Whole World is Watching: Mass Media in the Making and Unmaking of the New Left (California: University of California Press, 1990), 6.

Jeffers, Ann. Interpreting Magic and Divination in the Ancient Near East. Journal Religion Compass. Volume 1, Issue 6 November 2007, Pages 684-694 http://onlinelibrary.wiley.com/doi/ 10.1111/j.1749-8171.2007.00047. $\mathrm{x} /$ full

Jeffers, Ann. Interpreting Magic and Divination in the Ancient Near East. Journal Religion Compass. Volume 1, Issue 6 November 2007 Pages 684-694 http://onlinelibrary. wiley.com/doi/10.1111/j.17498171.2007.00047.x/full

Jones, Graham M.. Magic with a Message: The Poetics of Christian Conjuring. Journal Cultural Anthropology. Volume 27, Issue 2 May 2012 Pages 193-214 http://onlinelibrary.wiley.com/doi/ $10.1111 / \mathrm{j} .1548-$ 1360.2012.01140.x/full

Leddington, Jason. The Experience of Magic. The Journal of Aesthetics and Art Criticism. Volume 74, Issue 3 Summer 2016. Pages 253264 http://onlinelibrary.wiley. com/doi/10.1111/jaac.12290/full

Moeran, Brian. Business, Anthropology, and Magical Systems: The Case of Advertising. Journal Ethnographic Praxis in Industry 
Conference. Volume 2014, Issue 1

October 2014, Pages 119-132.

http://onlinelibrary.wiley.com/doi/ 10.1111/1559-8918.01016/ full.

Monagan, Alfrieta Parks. The Anthropology of Magic. by Susan Greenwood. New York: Berg, 2009. p. 159. Journal Anthropology and Humanism. Volume 38, Issue 1 June 2013, Pages 102-103.

Morgain, Rachel. Special Issue: Anthropological Theologies: Engagements and Encounters. The Alchemy of Life: Magic, Anthropology and Human Nature in a Pagan Theology. The Australian Journal of Anthropology. Volume 24, Issue 3 December 2013 Pages 290-309. http://onlinelibrary.wiley.com/doi/ 10.1111/ taja.12052/full

Mosko, Mark S.. Cards on Kiriwina: Magic, Cosmology, and the 'Divine Dividual' in Trobriand Gambling. Journal Oceania. Volume 84, Issue 3 November 2014 Pages 239-255.

http://onlinelibrary.wiley.com/doi/ 10.1002/ocea.5058/full.

Nardi, Peter M.. Toward a Social Psychology of Entertainment Magic (Conjuring). Journal Symbolic Interaction. Volume 7, Issue 1 Spring 1984 Pages 25-42 http://online library.wiley.com/doi/10.1525/si. 1984.7.1.25/full

Palmer, Craig T., Lyle B. Steadman, Chris Cassidy, Kathryn Coe. The Importance of Magic to Social Relationships. Zygon Journal of Religion \& Science. Volume 45, Issue 2 June 2010, Pages 317-337. http://onlinelibrary.wiley.com/doi/ 10.1111/j.14679744.2010. 01083.x/full.

Rider, Catherine . Magic and Impotence: Recent Developments in Medieval Historiography. Journal History Compass. Volume 5, Issue 3 May 2007 Pages 955-962. http://onlinelibrary.wiley.com/doi/ $10.1111 / \mathrm{j} .1478$ 0542.2007.00431.x/full

Rosengren, Karl S., Anne K. Hickling. Seeing Is Believing: Children's Explanations of Commonplace, Magical, and Extraordinary Transformations. Journal Child Development. Volume 65, Issue 6 December 1994 Pages: 16051626.

http://onlinelibrary.wiley.com/ doi/10.1111/j.1467-

8624.1994.tb00838.x/full

Rountree, Kathryn. How Magic Works: New Zealand Feminist Witches' Theories of Ritual Action. Journal Anthropology of Consciousness. Volume 13, Issue 1 March 2002 Pages 42-59. http://onlinelibrary.wiley.com/doi/ 10.1525/ac.2002.13.1.42/full.

Sack, Robert David. Magic And Space. Journal Annals of the Association of American Geographers. Volume 66, Issue 2 June 1976 Pages 309-321 http://onlinelibrary. wiley.com/doi/10.1111/j.14678306.1976.tb01092.x/full

Schippers, Michaéla C., Paul A. M. Van Lange. The Psychological Benefits of Superstitious Rituals in Top Sport: A Study Among Top Sportspersons. Journal of Applied Social Psychology. Volume 36, 
Issue 10 October 2006, Pages 2532-2553. http://onlinelibrary. wiley.com/doi/10.1111/j.00219029.2006.00116.x/full.

Segal, Robert A.. Jung and Lévy-Bruhl. The Journal of Analytical Psychology. Volume 52, Issue 5 November 2007 Pages 635-658. http://onlinelibrary.wiley.com/doi/ $10.1111 / \mathrm{j} .1468$ 5922.2007.00690.x/full

Segal, Robert A.. Jung as Psychologist of Religion and Jung as Philosopher of Religion. The Journal of Analytical Psychology. Volume 55, Issue 3 June 2010 Pages 361384.

http://onlinelibrary.wiley.com/doi/ $10.1111 /$ j.14685922.2010.01848.x/full

Segal, Robert A.. Jung's Very Twentiethcentury View of Myth. The Journal of Analytical Psychology. Volume 48, Issue 5 November 2003 Pages 593-617. http://online library.wiley.com/doi/10.1111/14 65-5922.00422/full.

Subbotsky, Eugene. Can Magical Intervention Affect Subjective Experiences? Adults' Reactions to Magical Suggestion. British Journal of Psychology. Volume 98, Issue 4 November 2007. http://onlinelibrary.wiley.com/doi/ 10.1348/000712608X368270/full

Subbotsky, Eugene. Children's and Adults' Reactions to Magical and Ordinary Suggestion: Are Suggestibility and Magical Thinking Psychologically Close Relatives? British Journal of Psychology. Volume 98, Issue 4 November 2007 Pages 547-574. http://onlinelibrary.wiley.com/doi/ 10.1348/000712606X166069/full
Teigen, Karl Halvor., Pia C. Evensen, Dimitrij K. Samoilow, and Karin B. Vatne. Good Luck and Bad Luck: How to Tell the Difference. European Journal OF Social Psychology. Volume 29, Issue 8 December 1999 Pages 981-1010. http://onlinelibrary.wiley.com/ doi/10.1002/(SICI)10990992(199912)29:8\%3C981::AIDJSP966\%3E3.0. CO;2-Z/full

Van Gent, Jacqueline. Current Trends in Historical Witchcraft Studies. Journal of Religious History. Volume 35, Issue 4 December 2011 Pages 601-613 http://onlinelibrary.wiley.com/doi/ 10.1111/j.14679809.2011.01144.x/ full

Woolley, Jacqueline D., Katrina E. Phelps, Debra L. Davis, and Dorothy J. Mandell. Where Theories of Mind Meet Magic: The Development of Children's Beliefs about Wishing. Journal Child Development. Volume 70, Issue 3 May/June 1999 Pages 571-587. http://onlinelibrary.wiley.com/doi/ 10.1111/1467-8624.00042/full 